\title{
STUDIES ON NEOPLASMS WITH THE AID OF RADIOACTIVE PHOSPHORUS. II. THE PHOSPHORUS METABOLISM \\ OF THE NUCLEOPROTEIN, PHOSPHOLIPID AND ACID SOLUBLE FRACTIONS OF NORMAL AND LEUKEMIC MICE
}

\author{
By L. W. TUTTLE, L. A. ERF, AND J. H. LAWRENCE \\ (From the Radiation Laboratory, University of Califormia, Berkeley)
}

(Received for publication September 10, 1940)

Previous studies $(1,2)$ have shown that the phosphorus metabolism of mouse tissues is markedly altered by leukemic infiltration, the absorption and retention of radio-phosphorus being increased in the tissues of leukemic animals. The present work goes one step further in elucidating the seat of this altered phosphorus metabolism by fractionating the tissues into the three broad groups of biologically active phosphorus compounds : the phospholipid, nucleoprotein, and acid soluble fractions.

\section{EXPERIMENTAL}

Twenty-five male and twenty-five female mice of the highly inbred and genetically uniform Strong A strain and of the same age (seven weeks) and weight (16.5 to 17 grams) were inoculated intraperitoneally with 0.1 $\propto$. of a suspension containing fifteen million leukemic cells (3). (This method of inoculation has the advantage of producing a localized tumor mass in the peritoneum and a very uniform generalized leukemic infiltration of the liver, spleen, and lymph nodes.) This lymphoma, which is highly vascular, non-necrotic, and has very little stroma, has been transferred about eighty times in the A strain of mice. It takes in 100 per cent of the mice inoculated, and regressions have not been observed. A similar group of twenty-five male and twenty-five female animals was retained as controls. Five groups of animals, consisting of five males and five females, respectively, with five corresponding groups of controls, were placed in twenty wire-bottomed cages.

The leukemic animals were fed Purina dog chow ad lib. The weighed daily food consumption of each group of leukemic animals determined the amount fed to its respective group of control animals on the following day. In addition, each group of five animals received six grams of whole oats per day and ten grams of fresh lettuce every other day. Thus the phosphorus and caloric intake of the leukemic and control animals was approximately the same.

The radio-phosphorus was administered by intraperitoneal injection of 0.5 cc. of a solution containing 7.5 mgm. sodium phosphate at $\mathrm{pH} 7.4$ and emitting 5.5 micro- curies ${ }^{1}$ of beta activity at the time the first group was injected. Ten leukemic and ten normal animals were given this solution seven, five, three and one-half, two, and one-quarter days before all the animals were killed, which occurred on the eighteenth day after inoculation with leukemic cells. At this time the weights of leukemic and control animals were approximately the same.

At autopsy, all leukemic animals had peritoneal tumors weighing about 800 to $1,000 \mathrm{mgm}$. and had uniformly enlarged spleens, livers and lymph nodes-both central and peripheral. These tissues (tumor, liver, spleen and lymph nodes) from the animals of each group were pooled, weighed and prepared for analysis. The weighed tissue was ground thoroughly under 95 per cent alcohol with the aid of a little sand and transferred to $100 \mathrm{cc}$. centrifuge tubes. The carcasses of each normal and leukemic group were pooled, ashed and assayed for radioactivity.

\section{METHODS OF TISSUE FRACTIONATION}

A. Phospholipid. The tissue phospholipid was removed by four successive extractions, the first with 95 per cent alcohol and the other three with 3:1 alcohol: ether. Seventy cc. of solvent were used in each extraction which was carried out at 50 to $55^{\circ} \mathrm{C}$. under a reflux condenser. The tubes containing the tissue were centrifuged after each extraction and the solvent decanted. The total duration of extraction was thirty-six hours.

The combined alcohol and ether extracts were evaporated at low temperature to a volume of about $2 \mathrm{cc}$. Five cc. of water were added and the mixture transferred to a separatory funnel where it was extracted five times with $70 \mathrm{cc}$. portions of petroleum ether. The combined petroleum ether extracts were evaporated down to a small volume, transferred to ashing capsules, ignited, and set aside for analysis. The aqueous phase which contained only a small amount of activity was added to the acid soluble fraction, since it contained some of the simpler non-lipid compounds removed from the tissue in the course of the alcohol extractions.

\footnotetext{
1 Preliminary experiments had shown that this amount of radioactivity administered to mice caused no observable metabolic changes which could be termed "radiation effects." The effects of increased doses of radioactive phosphorus upon the activity curves obtained in this type of study will be reported later.
} 
TABLE I

Differential uptake of labeled-phosphorus in various fractions of normal and leukemic mice

\begin{tabular}{|c|c|c|c|c|c|c|c|c|c|}
\hline \multirow{2}{*}{ Tissue } & \multirow{2}{*}{$\begin{array}{c}\text { Normal or } \\
\text { leukemic } \\
\text { mice }\end{array}$} & \multicolumn{3}{|c|}{ Nucleoprotein } & \multicolumn{2}{|c|}{ Phospholipid } & \multicolumn{3}{|c|}{ Acid soluble } \\
\hline & & $\begin{array}{l}\text { Per cent } \\
\text { of doee* } \\
\text { per gram }\end{array}$ & $\begin{array}{c}\text { Per cent } \\
\text { of } \\
\text { normal }\end{array}$ & $\begin{array}{c}\text { Per cent } \\
\text { per } \\
\text { mgm. } \mathbf{P}\end{array}$ & $\begin{array}{l}\text { Per cent } \\
\text { of dose** } \\
\text { per gram }\end{array}$ & $\begin{array}{c}\text { Per cent } \\
\text { of } \\
\text { normal }\end{array}$ & $\begin{array}{l}\text { Per cent } \\
\text { of dooe* } \\
\text { per gram }\end{array}$ & $\begin{array}{c}\text { Per cent } \\
\text { of } \\
\text { normal }\end{array}$ & $\begin{array}{l}\text { Per cent } \\
\text { per } \\
\text { mgm. } P\end{array}$ \\
\hline $\begin{array}{c}\text { One-quarter day } \\
\text { Tumor...... }\end{array}$ & & 0.92 & & 0.32 & 0.14 & & 1.51 & & 1.96 \\
\hline$\underset{\text { Liver } . \ldots \ldots \ldots \ldots \ldots}{\operatorname{Liver}}$ & $\mathbf{L}$ & $\begin{array}{l}0.96 \\
0.50\end{array}$ & 192 & $\begin{array}{l}0.43 \\
0.30\end{array}$ & $\begin{array}{l}0.83 \\
2.18\end{array}$ & 37 & $\begin{array}{l}1.36 \\
1.30\end{array}$ & 105 & $\begin{array}{l}1.70 \\
1.83\end{array}$ \\
\hline $\begin{array}{l}\text { Spleen } \ldots \ldots \ldots \ldots \ldots \\
\text { Spleen } \ldots \ldots \ldots \ldots \ldots\end{array}$ & $\mathbf{L}$ & $\begin{array}{l}1.45 \\
1.83\end{array}$ & 79 & $\begin{array}{l}0.49 \\
0.68\end{array}$ & $\begin{array}{l}0.20 \\
0.48\end{array}$ & 42 & $\begin{array}{l}2.92 \\
2.17\end{array}$ & 135 & $\begin{array}{l}3.50 \\
3.02\end{array}$ \\
\hline $\begin{array}{l}\text { Lymph nodes } \ldots \ldots \ldots \\
\text { Lymph nodes . . . . . }\end{array}$ & $\mathbf{L}$ & $\begin{array}{l}1.22 \\
0.65\end{array}$ & 188 & $\begin{array}{l}0.43 \\
0.27\end{array}$ & $\begin{array}{l}0.23 \\
0.25\end{array}$ & 92 & $\begin{array}{l}2.42 \\
1.23\end{array}$ & 197 & $\begin{array}{l}3.31 \\
1.89\end{array}$ \\
\hline $\begin{array}{l}\text { Two days } \\
\qquad \text { Tumor } \ldots \ldots \ldots \ldots \ldots\end{array}$ & & 3.08 & & 1.07 & 0.60 & & 0.92 & & 1.19 \\
\hline $\begin{array}{l}\text { Liver } \ldots \ldots \ldots \ldots \ldots \\
\text { Liver } \ldots \ldots \ldots \ldots \ldots\end{array}$ & $\stackrel{\mathbf{L}}{\mathbf{N}}$ & $\begin{array}{l}1.97 \\
0.57\end{array}$ & 346 & $\begin{array}{l}0.90 \\
0.34\end{array}$ & $\begin{array}{l}0.96 \\
1.11\end{array}$ & 86 & $\begin{array}{l}0.95 \\
0.78\end{array}$ & 122 & $\begin{array}{l}1.19 \\
1.10\end{array}$ \\
\hline $\begin{array}{l}\text { Spleen } \ldots \ldots \ldots \ldots \ldots \\
\text { Spleen } \ldots \ldots \ldots \ldots \ldots\end{array}$ & $\stackrel{\mathbf{L}}{\mathrm{N}}$ & $\begin{array}{l}3.56 \\
1.49\end{array}$ & 238 & $\begin{array}{l}1.21 \\
0.56\end{array}$ & $\begin{array}{l}0.47 \\
0.62\end{array}$ & 76 & $\begin{array}{l}1.42 \\
0.99\end{array}$ & 143 & $\begin{array}{l}1.71 \\
1.38\end{array}$ \\
\hline $\begin{array}{l}\text { Lymph nodes . . . . . . } \\
\text { Lymph nodes . . . . }\end{array}$ & $\stackrel{\mathbf{L}}{\mathbf{N}}$ & $\begin{array}{l}3.39 \\
0.98\end{array}$ & 346 & $\begin{array}{l}1.19 \\
0.40\end{array}$ & $\begin{array}{l}0.47 \\
0.43\end{array}$ & 109 & $\begin{array}{l}1.10 \\
0.60\end{array}$ & 183 & $\begin{array}{l}1.51 \\
0.92\end{array}$ \\
\hline $\begin{array}{l}\text { Three and one-half days } \\
\text { Tumor } \ldots \ldots \ldots \ldots \ldots\end{array}$ & & 2.68 & & 0.93 & 0.47 & & 0.84 & & 1.09 \\
\hline$\underset{\text { Liver } \ldots \ldots \ldots \ldots \ldots \ldots}{\text { Liver } \ldots \ldots \ldots}$ & $\stackrel{\mathbf{L}}{\mathbf{N}}$ & $\begin{array}{l}1.60 \\
0.61\end{array}$ & 262 & $\begin{array}{l}0.73 \\
0.36\end{array}$ & $\begin{array}{l}0.75 \\
0.84\end{array}$ & 89 & $\begin{array}{l}0.83 \\
0.52\end{array}$ & 160 & $\begin{array}{l}1.04 \\
0.73\end{array}$ \\
\hline $\begin{array}{l}\text { Spleen } \ldots \ldots \ldots \ldots \ldots \\
\text { Spleen } \ldots \ldots \ldots \ldots \ldots\end{array}$ & $\mathrm{L}$ & $\begin{array}{l}2.70 \\
1.27\end{array}$ & 212 & $\begin{array}{l}0.92 \\
0.47\end{array}$ & $\begin{array}{l}0.47 \\
0.55\end{array}$ & 85 & $\begin{array}{l}0.88 \\
0.76\end{array}$ & 116 & $\begin{array}{l}1.06 \\
1.05\end{array}$ \\
\hline $\begin{array}{l}\text { Lymph nodes } \ldots \ldots \ldots \\
\text { Lymph nodes } \ldots \ldots \ldots\end{array}$ & $\stackrel{\mathbf{L}}{\mathbf{N}}$ & $\begin{array}{l}2.70 \\
0.72\end{array}$ & 375 & $\begin{array}{l}0.95 \\
0.30\end{array}$ & $\begin{array}{l}0.49 \\
0.33\end{array}$ & 148 & $\begin{array}{l}0.75 \\
0.50\end{array}$ & 150 & $\begin{array}{l}1.02 \\
0.77\end{array}$ \\
\hline $\begin{array}{l}\text { Five days } \\
\text { Tumor. }\end{array}$ & & 2.22 & & 0.77 & 0.40 & & 0.67 & & 0.87 \\
\hline $\begin{array}{l}\text { Liver } \ldots \ldots \ldots \ldots \ldots \\
\text { Liver } \ldots \ldots \ldots \ldots \ldots\end{array}$ & $\stackrel{\mathbf{L}}{\mathbf{N}}$ & $\begin{array}{l}1.43 \\
0.57\end{array}$ & 251 & $\begin{array}{l}0.66 \\
0.34\end{array}$ & $\begin{array}{l}0.63 \\
0.50\end{array}$ & 126 & $\begin{array}{l}0.64 \\
0.40\end{array}$ & 160 & $\begin{array}{l}0.80 \\
0.56\end{array}$ \\
\hline $\begin{array}{l}\text { Spleen } \ldots \ldots \ldots \ldots \ldots \\
\text { Spleen } \ldots \ldots \ldots \ldots \ldots\end{array}$ & $\underset{\mathbf{L}}{\mathbf{N}}$ & $\begin{array}{l}2.31 \\
0.96\end{array}$ & 240 & $\begin{array}{l}0.78 \\
0.34\end{array}$ & $\begin{array}{l}0.47 \\
0.31\end{array}$ & 152 & $\begin{array}{l}0.81 \\
0.54\end{array}$ & 150 & $\begin{array}{l}0.98 \\
0.75\end{array}$ \\
\hline $\begin{array}{l}\text { Lymph nodes } \ldots \ldots \ldots \\
\text { Lymph nodes } \ldots \ldots \ldots\end{array}$ & $\stackrel{\mathbf{L}}{\mathbf{N}}$ & $\begin{array}{l}2.36 \\
0.78\end{array}$ & 303 & $\begin{array}{l}0.83 \\
0.32\end{array}$ & $\begin{array}{l}0.33 \\
0.34\end{array}$ & 97 & $\begin{array}{l}0.79 \\
0.21\end{array}$ & 376 & $\begin{array}{l}1.08 \\
0.32\end{array}$ \\
\hline $\begin{array}{l}\text { Seven days } \\
\quad \text { Tumor } \ldots \ldots \ldots \ldots \ldots\end{array}$ & & 1.85 & & 0.64 & 0.35 & & 0.60 & & 0.78 \\
\hline $\begin{array}{l}\text { Liver } \ldots \ldots \ldots \ldots \ldots \\
\text { Liver } \ldots \ldots \ldots \ldots \ldots\end{array}$ & $\mathbf{L}$ & $\begin{array}{l}1.06 \\
0.41\end{array}$ & 258 & $\begin{array}{l}0.49 \\
0.25\end{array}$ & $\begin{array}{l}0.53 \\
0.36\end{array}$ & 147 & $\begin{array}{l}0.54 \\
0.29\end{array}$ & 186 & $\begin{array}{l}0.67 \\
0.41\end{array}$ \\
\hline $\begin{array}{l}\text { Spleen } \ldots \ldots \ldots \ldots \ldots \\
\text { Spleen . . . . . . . . . }\end{array}$ & $\mathbf{L}$ & $\begin{array}{l}1.82 \\
0.75\end{array}$ & 243 & $\begin{array}{l}0.62 \\
0.28\end{array}$ & $\begin{array}{l}0.31 \\
0.20\end{array}$ & 155 & $\begin{array}{l}0.63 \\
0.45\end{array}$ & 140 & $\begin{array}{l}0.76 \\
0.62\end{array}$ \\
\hline $\begin{array}{l}\text { Lymph nodes . . . . . . } \\
\text { Lymph nodes . . . . }\end{array}$ & $\mathbf{L}$ & $\begin{array}{l}1.61 \\
0.63\end{array}$ & 256 & $\begin{array}{l}0.57 \\
0.27\end{array}$ & $\begin{array}{l}0.33 \\
0.23\end{array}$ & 143 & $\begin{array}{l}0.84 \\
0.21\end{array}$ & 400 & $\begin{array}{l}1.15 \\
0.32\end{array}$ \\
\hline
\end{tabular}

* These figures represent the amount of activity found in the fractions obtained from one gram fresh tissue. 

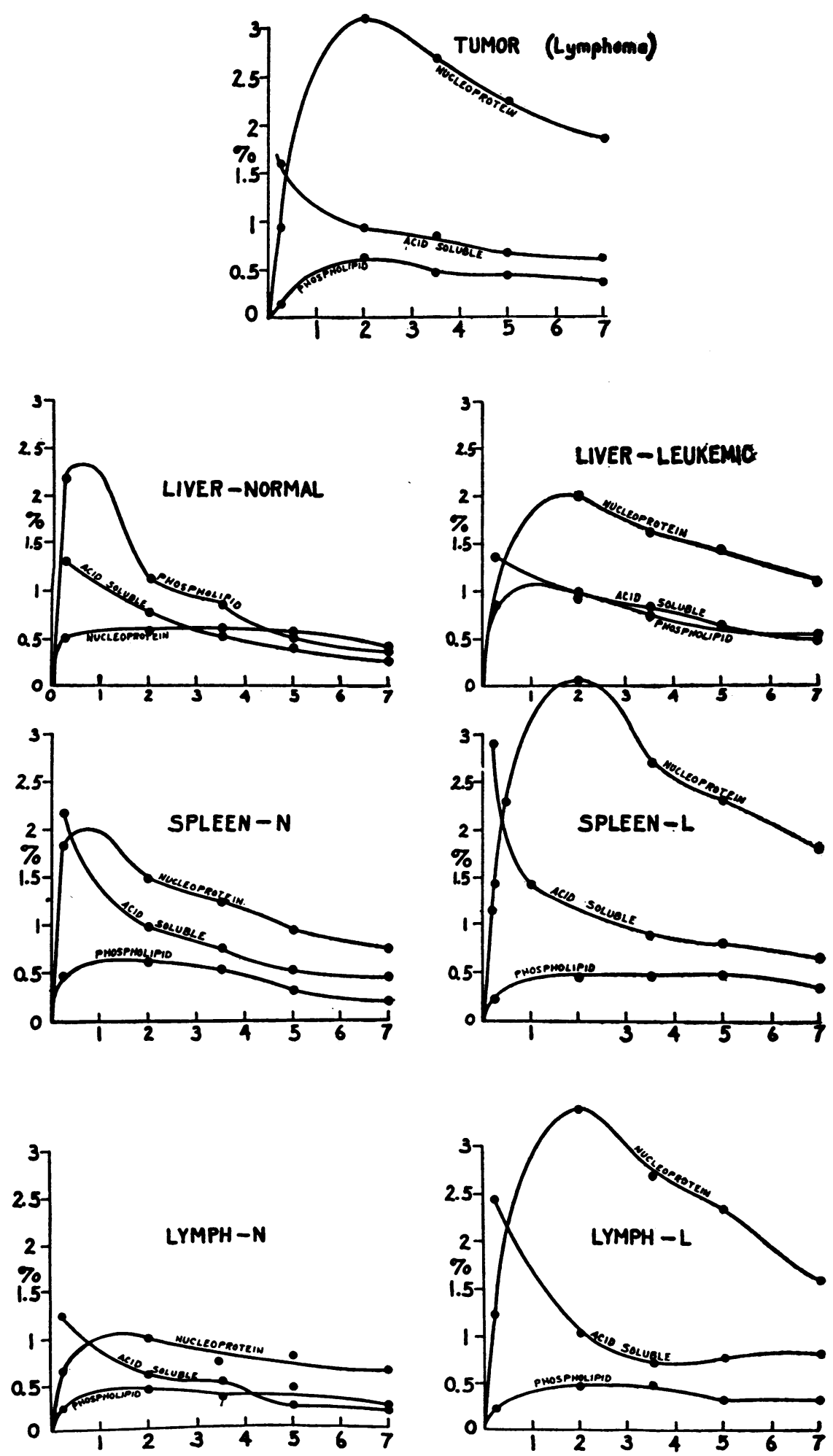

Fig. 1. The Comparative Uptake of Labeled-phosphorus in Normal and LEUKEMIC MICE 
B. Acid soluble. The tissue residue from which the phospholipid had been removed was then extracted with four 70 cc. portions of cold, 5 per cent trichloracetic acid. (Preliminary experiments had shown that the four extractions removed from 98 to 99 per cent of the activity which could possibly be extracted from the various tissues by this method.) Aliquot portions of the combined acid extracts were measured into ashing capsules for radioactivity and chemical analyses.

C. Nucleoprotein. The residual phosphorus contained in the tissues after the phospholipid and acid soluble fractions have been removed is termed "nucleoprotein" phosphorus although, in addition to nucleoprotein, this fraction probably contains some of the enzymes and coenzymes (pyroadenylic acid, the pyridine nucleotides, flavine enzyme, etc.) involved in the intermediate transfer of phosphorus, in combination with their respective protein carriers. The " nucleoprotein" fraction, upon microscopic examination, is seen to consist mainly of free, partially fragmented nuclei, along with a smaller amount of amorphous cytoplasmic material.

Measurements of radioactivity were made by the use of a DuBridge type of ion chamber electrometer. Phosphorus analyses were made by the method of Pregl (4).

\section{RESULTS}

The experimental data are presented in Table I. ${ }^{2}$ Six hours after the administration of tagged phosphorus, the carcass of each control mouse retained an average of 71.8 per cent of the dose; while each leukemic carcass retained 70.3 per cent. At two days, each control retained 40.4 per cent, each leukemic 50.6 per cent; at $31 / 2$ days, control 38.5 per cent, leukemic 47.4 per cent; at 5 days, control 29.1 per cent, leukemic 41.5 per cent; at 7 days, control 25.1 per cent, leukemic 40.8 per cent.

The mean phosphorus contents of the nucleoprotein fractions derived from one gram of the various fresh tissues were as follows: Lymphoma $2.88 \mathrm{mgm}$. P/gram; leukemic liver $2.18 \mathrm{mgm}$./ gram, normal liver $1.67 \mathrm{mgm} . / \mathrm{gram}$; leukemic spleen $2.95 \mathrm{mgm} . / \mathrm{gram}$; normal spleen 2.68 mgm./gram; leukemic lymph nodes $2.84 \mathrm{mgm} . /$ gram; normal lymph nodes $2.41 \mathrm{mgm} . / \mathrm{gram}$. For the acid soluble fractions the values were lymphoma $0.77 \mathrm{mgm}$. $\mathrm{P} / \mathrm{gram}$; leukemic liver 0.80 mgm./gram, normal liver $0.71 \mathrm{mgm} . / \mathrm{gram}$; leukemic spleen $0.83 \mathrm{mgm} . /$ gram, normal spleen 0.72 mgm./gram; leukemic lymph nodes $0.73 \mathrm{mgm}$./ gram, normal lymph nodes $0.65 \mathrm{mgm}$./gram.

2 Two other similar experiments, each involving over one hundred mice, gave practically identical results.
From Figure 1 it may be noted that for normal liver the activity curve of phospholipid is in keeping with a known function of liver in the synthesis of phospholipid. The curve indicates a very rapid incorporation of " tagged" phosphorus atoms into phospholipid and a rapid release of this phospholipid to other tissues. The relatively low, flat curve of nucleophosphorus activity in normal liver suggests that the turnover of nucleoprotein, insofar as phosphorus is concerned, is simply a metabolic phenomenon of tissue maintenance. No notably rapid synthesis of nucleoprotein or accelerated metabolism of the phosphorus transport systems is indicated for this tissue.

Normal spleen, which has a rôle in the destruction of the formed blood elements, and a possible function in the reorganization and resynthesis of their nucleoproteins, has a high order of nucleophosphorus activity indicative of intense nucleoprotein metabolism or synthesis. The phospholipid curve is low and relatively flat; one might infer that only the minimal exchange of phospholipid necessary for maintenance occurs.

Normal lymph nodes have a low level of phospholipid activity indicative of simple maintenance. The nucleophosphorus metabolism is intermediate between that of spleen and liver.

Lymphoma tissue is characterized by a very rapid incorporation of simple phosphate into nucleophosphate. The uptake is too rapid to be due to growth alone, and it seems reasonable to attribute it to some phase of phosphorus transport in glycolysis, which is a prominent metabolic feature of similar neoplasms of this type $(5,6)$.

After the infiltration of liver, spleen and lymphatic tissue by leukemic cells, a three- to fourfold increase is noted in the level of nucleoprotein activity. The activity curves of these tissues, in effect, tend to approach those of the pure lymphoma. The specific activity (activity per unit of phosphorus) in the nucleoprotein fraction of infiltrated liver, spleen and lymph nodes is severalfold higher than that of the corresponding normal tissues, although the phosphorus content of the leukemic tissues is only slightly increased over normal.

The curves of acid soluble activity for all the tissues show a sharp drop during the first few hours after the administration of the labelled phos- 
phorus, followed by a gradual decrease over a period of several days. The acid soluble activity curve for each leukemic tissue is maintained at a considerably higher level than that of its respective normal tissue. Since these acid soluble fractions contain the phosphorus esters of carbohydrates undergoing glycolysis, along with the free intermediate carriers (adenylic acid, creatine phosphate, and the various nucleotides), which are part of the phosphorylating mechanisms, a reasonable explanation for the observed increase in activity would be that the quantity of these intermediates is increased as a result of leukemic infiltration or that the rate at which the compounds exchange phosphorus in their metabolic cycles is increased. Since the specific activity, or activity per unit weight of phosphorus is higher in the acid soluble fraction of leukemic tissue than in normal, the latter view has greater weight.

The phospholipid curves for infiltrated spleen and lymph nodes are little different from normal. The effect of infiltration upon liver phospholipid appears to be limited to a depression of the "synthesis peak" (7) ; the curve after two days is only slightly higher than normal.

Preliminary experiments on the phosphorus metabolism of yeast cells ( $S$. cerevisiae) have shown that under fermentative conditions tagged phosphorus added to the external medium is very rapidly absorbed and converted to nucleophosphate. This, along with the rapid nucleophosphate exchange observed in tumor tissue, lends credence to the possibility that, in cells showing a high rate of carbohydrate cleavage, the phosphorylation of the intermediate phosphorus carriers involves their passage through the broad group of compounds which might fall under the generic term " nucleoprotein."

Further work to clarify the speculative points suggested by the findings of the present paper is in progress. A detailed study of the organic phosphorus compounds contained in the acid soluble and nucleoprotein fractions in the presence of selective toxins will be given later.

\section{SUMMARY AND CONCLUSIONS}

1. The manner in which a single tracer dose of radioactive phosphorus is handled over a period of seven days by the tissues of fifty normal and fifty leukemic mice has been determined.

2. Leukemic infiltration is accompanied by an increase of several-fold in the uptake and retention of radioactive phosphorus by the nucleoprotein and acid soluble fractions of mouse liver, spleen and lymph nodes.

3. The phospholipid metabolism of spleen and lymph nodes is affected to only a limited extent by leukemic infiltration, while that of liver is depressed only during the first day after the administration of tagged phosphorus.

4. The whole body retention of phosphorus administered to leukemic mice is higher than that of normal mice, but the rate of excretion over a period of seven days is approximately the same.

This investigation has been aided by a grant from The Jane Coffin Childs Memorial Fund for Medical Research. Radio-phosphorus has been made available through the generous cooperation of the staff of the Radiation Laboratory. One of us (L. A. E.) has been supported from funds granted to the Radiation Laboratory by the $\mathrm{Na}$ tional Advisory Cancer Council.

\section{BIBLIOGRAPHY}

1. Lawrence, J. H., and Scott, K. G., Comparative metabolism of phosphorus in normal and lymphomatous animals. Proc. Soc. Exper. Biol. and Med., 1939, 40, 694.

2. Lawrence, J. H., Tuttle, L. W., Scott, K. G., and Connor, C. L., Studies on neoplasms with the aid of radioactive phosphorus. I. The total phosphorus metabolism of normal and leukemic mice J. Clin. Invest., 1940, 19, 267.

3. Lawrence, J. H., and Gardner, W. U., A transmissible leukemia in the "A" strain of mice. Am. J. Cancer, 1938, 33, 112.

4. Pregl, F., and Roth, H., Quantitative Organische Analyse. Julius Springer, Berlin, 1935.

5. Victor, J., and Potter, J. S., Metabolic differences between 2 transmission lines of mouse leukemia. Proc. Soc. Exper. Biol. and Med., 1933, 30, 532.

6. Victor, J., and Wintersteiner, M. R., Studies in mouse leukemia. X. Metabolic differences between transmission lines of mouse lymphatic leukemia. Am. J. Cancer, 1934, 22, 561.

7. Jones, H. B., Chaikoff, I. L., and Lawrence, J. H., Radioactive phosphorus as an indicator of phospholipid metabolism. VI. The phospholipid metabolism of neoplastic tissues (mammary carcinoma, lymphoma, lymphosarcoma, sarcoma 180). J. Biol. Chem., 1939, 128, 631. 